\title{
Diagnosis of Pseudo-Arylsulfatase A Deficiency with Electrophoretic Techniques
}

\author{
PATRICIA L. CHANG, NADIA E. ROSA, PETER A. VAREY, HAYATO KIHARA, \\ EDWIN H. KOLODNY, AND RONALD G. DAVIDSON \\ Department of Pediatrics, McMaster University, Hamilton, Ontario, Canada L8N 3 Z5 [P.L.C., N.E.R., P.A.V., \\ R.G.D.J, University of California, Los Angeles School of Medicine, Neuropsychiatric Institute-Pacific State \\ Hospital Research Group, Pomona, California 91769 [H.K.], and Eunice Kennedy Shriver Center for Mental \\ Retardation, Inc., Walter E. Fernald State School, Waltham, Massachusetts 02254 [E.H.K.]
}

\section{Summary}

Deficient arylsulfatase $\mathrm{A}$ activity in man has long been associated with the neurodegenerative disease, metachromatic leukodystrophy. However, similar deficiency has been noted in clinically normal individuals, and is referred to as the pseudoarylsulfatase A deficiency condition. Although direct quantitative analysis of arylsulfatase $\mathrm{A}$ activity failed to differentiate between these two conditions, analysis of residual arylsulfatase $\mathbf{A}$ activity with either Cellogel electrophoresis or isoelectric focusing in polyacrylamide gels now has been shown to distinguish between them unequivocally. With both techniques, cultured fibroblasts from patients with pseudo-arylsulfatase A deficiency showed faint but clear bands of arylsulfatase $A$ activity. Under identical conditions, fibroblasts from patients with metachromatic leukodystrophy showed no trace of activity. These methods can be adapted easily for general laboratory analysis in cases when results from quantitative arylsulfatase $A$ assays are noninformative.

\section{Abbreviations}

ARSA, arylsulfatase A

MLD, metachromatic leukodystrophy

4-MUS, 4-methylumbelliferyl sulfate

$p$-NCS, $p$-nitrocatechol sulfate

$\mathrm{PD}$, pseudo-arylsulfatase A deficiency

Metachromatic leukodystrophy is a hereditary neurodegenerative disease characterized by accumulation of cerebroside sulfatides in tissues and is associated with deficient activity of ARSA (EC 3.1.6.1) (1, 15). The biochemical diagnosis of this condition can be accomplished by assaying for this enzyme activity in cultured fibroblasts (17) or white blood cells (16) with artificial substrates such as p-nitrocatechol sulfate (3) or 4-methylumbelliferyl sulfate (5) and the natural substrate cerebroside sulfatide $(15,18)$. Prenatal diagnosis, which is the only available method for prevention of this severe and untreatable disease, is carried out by assay of ARSA activity in cultured amniotic fluid cells $(22,24)$.

Since 1975, through screening of the general population or family members of MLD probands, individuals have been iden-

Received September 9, 1983; February 10, 1984

Correspondence may be addressed to Dr. P. L. Chang, Room 3N18, Department of Pediatrics, McMaster University, 1200 Main Street West, Hamilton, Ontario, Canada L8N 3 Z5.

Support from the Ontario Mental Health Foundation and Medical Research Council of Canada (MA-5789) and the award of a Velleman Scholarship to P. L

C. are gratefully acknowledged. tified who were similarly deficient in ARSA activity, regardless of whether natural or artificial substrates were used for the assays $(4,7,8,13)$. The paradox is that these individuals, now called $\mathrm{PD}$, were free from any clinical manifestations of the disease.

It thus became critical to differentiate between MLD and PD when both types of individuals were identified in the same family for which prenatal diagnosis of a fetus at risk for MLD had to be made. Although conventional assay methods failed to distinguish between these two conditions, the diagnosis was accomplished by means of the sulfatide-loading test (11). In this test, radioactive cerebroside sulfatides were supplied to the cultured amniotic cells. In MLD cells, the exogenous substrate simply accumulated inside the cell without degradation. In PD cells, the substrates did not accumulate but were degraded normally.

We now report a simple electrophoretic method for the diagnosis of MLD and PD in cultured fibroblasts that also allows for unequivocal differentiation between these two conditions.

\section{MATERIALS AND METHODS}

Tissue culture. Cultured fibroblasts were maintained in minimal essential medium-4-(2-hydroxyethyl)-1-piperazineethanesulfonic acid supplemented with $10 \%$ fetal bovine serum and 2 $\mathrm{mM}$ L-glutamine, and kept under $5 \% \mathrm{CO}_{2}$ in air and $100 \%$ humidity at $37^{\circ} \mathrm{C}$. Cultured cells at confluency were harvested by trypsinization and washed twice with $0.9 \% \mathrm{NaCl}$, and the cell pellets were stored at $-70^{\circ} \mathrm{C}$ until use.

Fibroblasts used as controls were established from skin biopsies of individuals without any known metabolic disease. Fibroblasts from PD and MLD patients were established from skin biopsies. Diagnosis was based on the clinical finding of progressive deterioration of neural motor functions in MLD cases, on assays for arylsulfatase A activity, excessive urinary excretion of sulfatides, and/or sulfatide loading tests (9).

For preparing the soluble extract containing ARSA, cell pellets were suspended in $0.05 \mathrm{M}$ acetate buffer, $\mathrm{pH}$ 5.6, disrupted by sonication for three bursts at power setting 4 with the microultrasonic cell disruptor (Kontes, Vineland, $\mathrm{NJ}$ ), and centrifuged at $103,000 \times g$ for $10 \mathrm{~min}$ at $4-10^{\circ} \mathrm{C}$. The supernatants were obtained for ARSA and protein determinations before using for electrophoresis with Cellogel or isoelectric focusing with polyacrylamide electrophoresis.

ARSA activity was determined according to the method of Chang et al. (5) with 4-MUS and the method of Baum et al. (3) with $p$-NCS as the substrate. A unit of enzyme activity was defined as nanomoles of 4-MUS or p-NCS hydrolyzed per $\mathrm{h}$ at $37^{\circ} \mathrm{C}$.

Electrophoresis with cellulose acetate (Cellogel, $17 \times 17 \mathrm{~cm}$, Chemetron, Italy) was carried out at $\mathrm{pH} 7.0$ according to the 
method of Rattazzi et al. (19) and isoelectric focusing was in polyacrylamide gels as described by Chang and Davidson (6). Briefly, 100 or $300 \mu \mathrm{g}$ of protein from cell extracts in $70 \mu \mathrm{l}$ containing $10 \mu \mathrm{l}$ of $80 \%$ glycerol and $10 \mu \mathrm{l}$ of Ampholine ( $\mathrm{pH}$ $3.5-10)$ were loaded onto each tube gel $(5 \times 115 \mathrm{~mm})$. The composition of the separating gels was as follows. For six gels, mix $3.75 \mathrm{ml}$ of $20 \%(\mathrm{w} / \mathrm{v})$ acrylamide $(10 \mathrm{~g}$ of acrylamide and $0.4 \mathrm{~g}$ of bisacrylamide in $50 \mathrm{ml}$ of distilled water); $1.875 \mathrm{ml}$ of $80 \%$ (v/v) glycerol in distilled water; $0.75 \mathrm{ml}$ Ampholines $(\mathrm{pH}$ $3-10: 4-6,1: 4) ; 1.116 \mathrm{ml}$ of distilled water. Deaerate for $2 \mathrm{~min}$ and then add $9 \mu \mathrm{l}$ of $N, N, N^{\prime}, N^{\prime}$-tetramethylethylenediamine and $7.50 \mathrm{ml}$ of fresh deaerated ammonium persulfate $(0.5 \mathrm{mg} / \mathrm{ml}$ of distilled water). The cathode buffer was $0.04 \mathrm{M} \mathrm{NaOH}$ and the anode buffer was $0.01 \mathrm{M} \mathrm{H}_{3} \mathrm{PO}_{4}$ (prepared by $0.68 \mathrm{ml}$ of $85 \%$ $\mathrm{H}_{3} \mathrm{PO}_{4}$ in 1 liter of distilled water). Each gel was focused under refrigeration at $2-4^{\circ} \mathrm{C}$ with $0.5 \mathrm{~mA}$ for $0.5 \mathrm{~h}$, then $1 \mathrm{~mA}$ until the voltage reached $1000 \mathrm{~V}$, and then continued at constant voltage for a total of $4.5 \mathrm{~h}$. The gels were stained for arylsulfatase activity with 4-MUS and photographed without further enhancement with alkaline buffer.

\section{RESULTS}

Twenty cultured cell strains obtained from individuals who were normal, or diagnosed to have PD or MLD, were coded so that all the analyses were performed without knowledge of the identity of the samples.

ARSA activity was assayed in the soluble extracts. Each group of assays was performed with controls from normal, known PD, and known MLD cell strains (Table 1). The specific ARSA activity of these 20 cell strains fell into two groups. One showed

Table 1. Summary of quantitative assays and qualitative electrophoresis

\begin{tabular}{|c|c|c|c|c|c|}
\hline \multirow[b]{2}{*}{ Cell strain } & \multicolumn{2}{|c|}{ ARSA* } & \multirow{2}{*}{$\begin{array}{l}\text { Cello- } \\
\text { gel } \dagger\end{array}$} & \multirow{2}{*}{$\begin{array}{l}\text { Isoelectric } \\
\text { focusing } \dagger\end{array}$} & \multirow[b]{2}{*}{ Diagnosis } \\
\hline & 4-MUS & $p$-NCS & & & \\
\hline Normal control & $167 \pm 74$ & 935 & +++ & +++ & \\
\hline PD control & $47.0 \pm 28.0$ & 96 & + & + & \\
\hline MLD control & $41.0 \pm 21.0$ & 38 & - & - & \\
\hline \multicolumn{6}{|l|}{ Group A } \\
\hline 579 & $176 \pm 67$ & 612 & ++ & ++ & $\mathrm{N}$ \\
\hline 623 & $150 \pm 23$ & 660 & +++ & +++ & $\mathrm{N}$ \\
\hline 624 & $105 \pm 1$ & 260 &,+++ & + & $\mathrm{N}$ \\
\hline 631 & $158 \pm 11$ & ND & +++ & +++ & $\mathrm{N}$ \\
\hline 632 & $181 \pm 1$ & 578 & +++ & +++ & $\mathrm{N}$ \\
\hline 633 & $277 \pm 15$ & 1180 & +++ & +++ & $\mathrm{N}$ \\
\hline \multicolumn{6}{|l|}{ Group B } \\
\hline 619 & $81.0 \pm 25.0$ & 76.3 & + & + & PD \\
\hline 630 & $87.0 \pm 36.0$ & 84.4 & + & + & PD \\
\hline 3475 & $44.0 \pm 37.0$ & 70.2 & + & + & PD \\
\hline 3519 & $13.0 \pm 2.0$ & 101 & + & + & PD \\
\hline 4087 & $19.0 \pm 3.0$ & 66.0 & + & + & PD \\
\hline 4835 & $33.0 \pm 17.0$ & 86.3 & + & + & PD \\
\hline \multicolumn{6}{|l|}{ Group C } \\
\hline 576 & $39.0 \pm 32.0$ & 32.5 & - & - & MLD \\
\hline 577 & $74.0 \pm 8.0$ & 45.7 & - & - & MLD \\
\hline 1353 & $23.0 \pm 13.0$ & 29.0 & - & - & MLD \\
\hline 3072 & 27.0 & 33.9 & - & - & MLD \\
\hline 3149 & $37.0 \pm 2.0$ & 38.1 & - & - & MLD \\
\hline 3585 & $20.0 \pm 7.0$ & ND & - & - & MLD \\
\hline 4839 & $48.0 \pm 22.0$ & 40.7 & - & - & MLD \\
\hline 5171 & $20.0 \pm 4.0$ & 31.9 & - & - & MLD \\
\hline
\end{tabular}

* Specific activity is measured as units/mg protein. With 4-MUS, each value is averaged from two ( \pm range) to six $( \pm$ SD) separate assays. Each assay was performed in duplicate. With $p$-NCS, each value is the average from duplicate determinations. The range of variation is about $\pm 10 \%$.

$\dagger-,+,++$, and +++ : not detectable, faint, medium, and strong, respectively. the normal range of activity (group A, Table 1), $167 \pm 74$ units/ $\mathrm{mg}$ protein when assayed with 4-MUS and about 935 units/mg protein with $p$-NCS. Strain 624 was not as clearly defined: its ARSA activity was slightly higher than the values in the deficient range, yet it had the lowest activity of the normal group, i.e. 105 units/mg protein (4-MUS) and 260 units/mg protein ( $p$-NCS). The second group showed deficient activity, ranging from 24$28 \%$ of normal when assayed with 4-MUS or $5-10 \%$ of normal with $p$-NCS. The results were compatible with the diagnosis of MLD (groups B and C, Table 1). However, the ARSA activity of three cell strains in this deficiency group $(619,630,577)$ was somewhat higher than the usual MLD range $(41 \pm 21$ units $/ \mathrm{mg})$ when assayed with the 4-MUS substrate, i.e. $81.0,87.0$, and 74.0 units/mg protein, respectively. When assayed with $p$-NCS as the substrate, they were within the usual deficient range of $5-10 \%$ of normal.

The 20 cell strains again were examined for ARSA activity with Cellogel electrophoresis. The normal group (A), as expected, showed prominent ARSA activity bands migrating towards the anode (Fig. 1, lane $N$ ). When the same amount of protein was loaded on each lane $(15 \mu \mathrm{g})$, the ARSA-deficient groups (B and C) showed two types of results. The first (group B) showed faint bands of ARSA activity with electrophoretic mobility similar to the normal ARSA but with much lower activity (lanes $P, 1,2$ in Fig. 1). The second type (group C) did not show any fluorescent activity bands in this region corresponding to ARSA (lanes $M$ and 3 in Fig. 1), which was the classical pattern for MLD. The arylsulfatase B activity bands at the cathodic end appeared normal in all cell strains studied. The results of Cellogel electrophoresis on all cell strains were summarized from two experiments in Table 1. When the two runs gave discordant results, both were indicated (see 624, Table 1).

The same cell strains were further examined with isoelectric focusing at $\mathrm{pH}$ 4-6 in polyacrylamide gels (Fig. 2). A pattern similar to that in Cellogel electrophoresis was observed. In group A (normal ARSA specific activity and intensity on Cellogel electrophoresis), loading each gel with $100 \mu \mathrm{g}$ of protein allowed the ARSA activity to resolve into at least six bands. These were of varying intensity, focusing between $\mathrm{pH} 4$ and 6 . If the same amount of protein $(100 \mu \mathrm{g})$ from the remaining cell strains (groups B and C) was loaded, no distinction could be observed among them and none showed any remarkable activity, as expected of ARSA-deficient cell strains.

When these ARSA-deficient cell strains were examined after overloading with $300 \mu \mathrm{g}$ of protein instead of $100 \mu \mathrm{g}$, two patterns emerged. The first type (lanes $P, 1$, and 2, Fig. 2), showed discernible bands of ARSA activity focusing at a $\mathrm{pH}$ range similar to the normal ARSA. The bands, however, were slightly shifted towards the alkaline range, i.e. the cathodic end. The number of activity bands in different cell strains varied. In some, only three bands were clearly visible (lane $P$ in Fig. 2 ). In others, five to six bands were observed (lanes 1 and 2, Fig. 2). The cell strains that showed ARSA activity bands on overloading coincided with group B with trace activity on Cellogel electrophoresis. The only exception was cell strain 624 from the group A normal subjects. It behaved as the group B cell strains in demonstrating activity only on overloading the gel.

The second type showed no discernible activity bands in this range of the $\mathrm{pH}$ gradient even when the gels were overloaded with $300 \mu \mathrm{g}$ of protein (lanes $M$ and 3, Fig. 2). These cell strains corresponded to group $\mathrm{C}$ with deficient ARSA activity by quantitative assays and no activity on Cellogel. The isoelectric focusing results of all cell strains are summarized from two separate experiments in Table 1 . They are completely concordant.

\section{DISCUSSION}

Based on the above results, fibroblast extracts from normal controls were identified on the basis of normal ARSA specific activity, normal electrophoretic mobility and normal intensity 


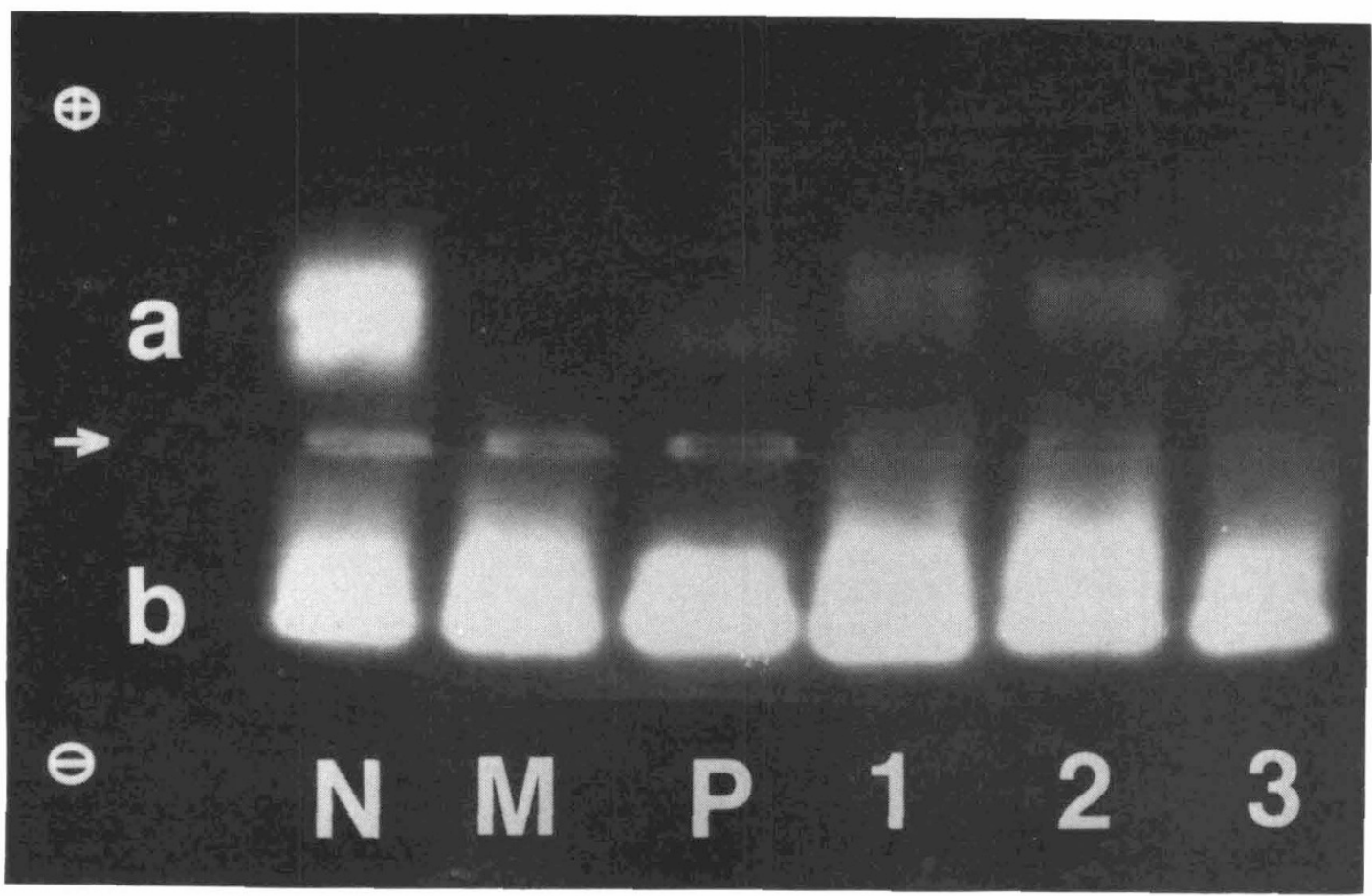

Fig. 1. Electrophoresis of arylsulfatases A and B from normal, PD, and MLD fibroblast extracts on Cellogel. $15 \mu \mathrm{g}$ of protein from fibroblast extracts of normal, PD, and MLD were applied. After electrophoresis for $3 \mathrm{~h}$ at $15 \mathrm{~mA}$, the gel was stained for arylsulfatase activity. $N$, normal control; $M$, MLD control; $P$, PD control; 1, 4835 (PD); 2, 3519 (PD); 3, 5171 (MLD). $a$, arylsulfatase A; $b$, arylsulfatase B; +, anode; -, cathode; $\rightarrow$, origin.

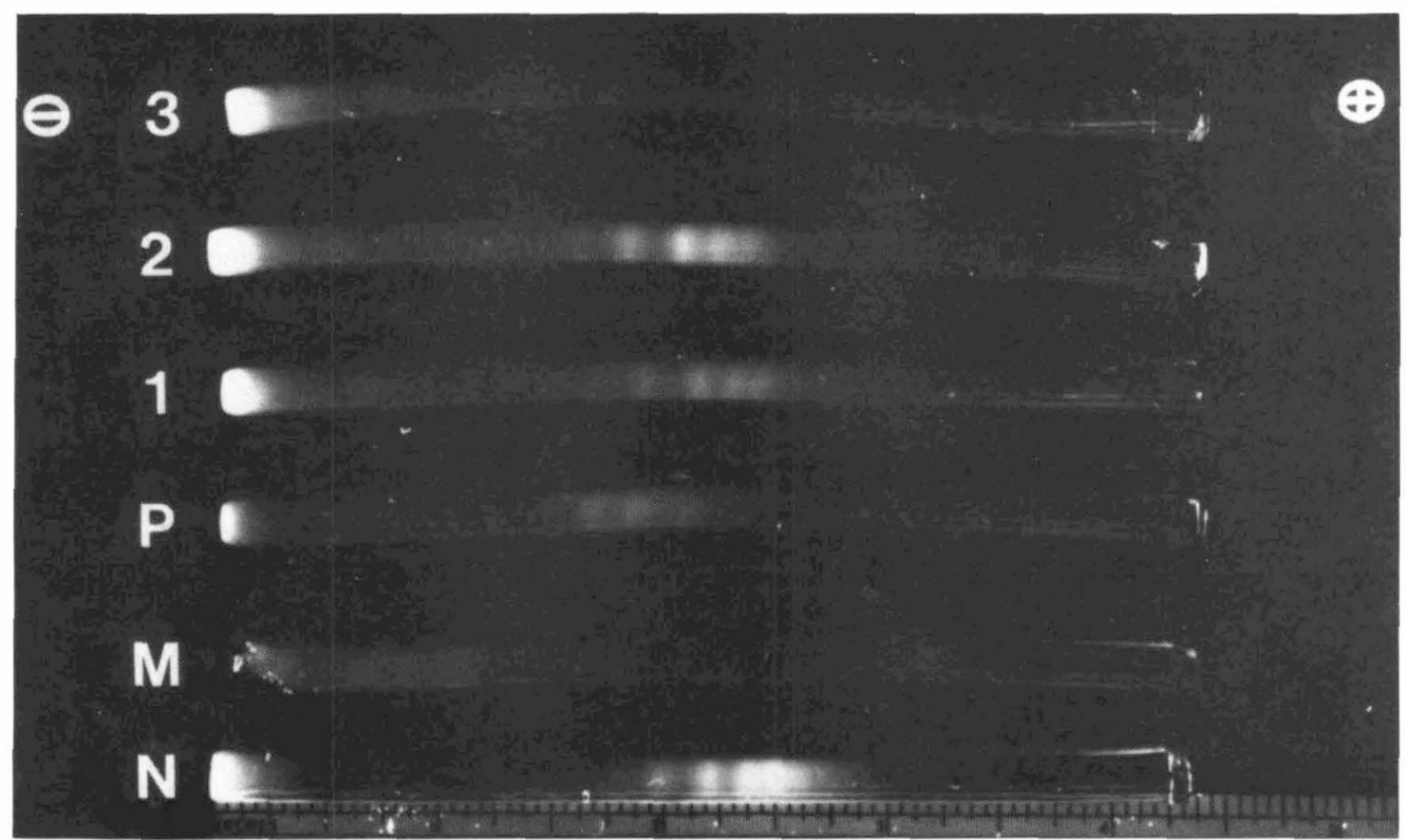

Fig. 2. Isoelectric focusing of arylsulfatase A from normal, PD, and MLD fibroblast extracts. Fibroblast extracts were prepared and subjected to isoelectric focusing as described in "Materials and Methods." The final pH gradient was from about $3.8(+)$ to $7.4(-)$. $N$, normal control (100 $\mu \mathrm{g}$ protein); $M$, MLD control (300 $\mu \mathrm{g}$ protein); $P$, PD control (300 $\mu \mathrm{g}$ protein); 1, 4835, PD (300 $\mu \mathrm{g}$ protein); 2, 3519, PD (300 $\mu \mathrm{g}$ protein); 3, 5171, MLD (300 $\mu$ g protein). +, anode; -, cathode.

on both Cellogel and polyacrylamide isoelectric focusing. The diagnosis of PD was based on deficient ARSA specific activity, trace activity discernible on Cellogel electrophoresis, and well defined activity bands by overloading the isoelectric focusing gel with $300 \mu \mathrm{g}$ of protein instead of $100 \mu \mathrm{g}$. The diagnosis of MLD was based on deficient ARSA specific activity, no discernible activity in Cellogel electrophoresis, and no activity in isoelectric focusing even on overloading (Table 1). The only equivocal case 
was 624. It may be classified as either normal because of its slightly higher ARSA activity than those of the deficient cell strains or as PD because of its isoelectric focusing behavior. In no case was there any ambiguity between MLD and PD.

Recent reports from Fluharty et al. (10) and Bach and Neufeld (2) showed that a band(s) of immunologically cross-reacting material to ARSA was found in PD cultured fibroblasts. Under denaturing conditions, these had the smaller molecular weight of about 56,000 and 59,000, compared to the normal subunit sizes of 59,000 and 63,000 (20). Therefore, the PD condition appears related to a structural mutation in the ARSA subunits.

Under the nondenaturing conditions of isoelectric focusing in polyacrylamide, we observed more heterogeneity in the residual arylsulfatase activity bands among different PD cell strains. Among the normal subjects, ARSA usually focused into at least six bands at $\mathrm{pH}$ values of about 5.36, 5.26, 5.11, 4.99, 4.91, and 4.86 (6) although the relative intensities of these bands varied, depending on the cell strain (unpublished observation). In some PD strains, there were only two to three major bands near the cathodic end (lane P, Fig. 2) while in others, there may be five to six bands (lanes 1 and 2 in Fig. 2), all of which seemed to be slightly shifted towards the alkaline range but by only $<0.1 \mathrm{pH}$ unit. Thus, it is possible that the structural mutation in PD not only involves a reduction in the size of the subunits $(2,10)$ but also changes in charge groups. The exact changes may vary in different PD individuals.

Even in the "normal" population (as defined by those not affected with MLD), there seems to be two allelic variant forms of the ARSA subunits (23). In some individuals, only a 59.5$\mathrm{kDa}$ precursor form was synthesized while in others, only a 62 $\mathrm{kDa}$ precursor form was synthesized. Individuals who have both forms were considered heterozygotes. Such allelic variations of the normal enzyme subunits may account for the heterogeneous residual ARSA bands observed among the different PD individuals.

The genetic status of the PD condition now appears to be clarified. Both family studies $(12,21,25)$ and somatic cell hybrid complementation studies (6) indicate that PD and MLD result from allelic variations, arising from structural mutations of the ARSA locus. However, the possible genotypes of the individuals, as described by Schaap et al. (21), cannot be ascertained in the present method because the various permutations of the three alleles, normal, $P D$, or $M L D$, can give rise to overlapping values of ARSA activity. The chief benefit with these electrophoretic analyses appears only to distinguish between the clinically affected and nonaffected phenotypes.

Although the exact molecular defect of the PD condition remains to be defined, it is clearly related to changes in charge and size of the ARSA molecule. This condition can be distinguished now from MLD in cultured fibroblasts, with relatively simple techniques and reagents that are readily available commercially. Its application to prenatal diagnosis in cultured amniotic fluid cells still needs to be confirmed.

\section{REFERENCES}

1. Austin J, McAfee D, Armstrong D, O'Rourke M, Shearer L, Bachhawat B 1964 Abnormal sulfatase activities in two human diseases (metachromatic leukodystrophy and gargoylism). Biochem J 93:15C

2. Bach G, Neufeld EF 1983 Synthesis and maturation of cross-reactive glycoprotein in fibroblasts deficient in arylsulfatase A activity. Biochem Biophys Res Commun 112:198

3. Baum H, Dodgson KS, Spencer B 1959 The assay of arylsulfatases A + B in a human urine. Clin Chim Acta 4:453

4. Butterworth J, Broadhead DM, Keay AJ 1978 Low arylsulfatase A activity in a family without metachromatic leukodystrophy. Clin Genet 14:213

5. Chang PL, Rosa NE, Davidson RG 1981 Differential assay of arylsulfatase A and $B$ activities: a sensitive method for cultured human cells. Anal Biochem 117:382

6. Chang PL, Davidson RG 1983 Pseudo arylsulfatase-A deficiency in healthy individuals_-genetic and biochemical relationship to metachromatic leukodystrophy. Proc Natl Acad Sci USA 80:7323

7. Dubois G, Turpin J, Baumann N 1975 Absence of ASA activity in healthy father of a patient with metachromatic leukodystrophy. N Engl J Med 293:302

8. Dubois G, Harzer K, Baumann N 1977 Very low arylsulfatase A and cerebroside sulfatase activities in leukocytes of healthy members of metachromatic leukodystrophy family. Am J Hum Genet 29:191

9. Fluharty AL, Stevens RL, Kihara H 1978 Cerebroside sulfate hydrolysis by fibroblasts from a metachromatic leukodystrophy parent with deficient arylsulfatase A. J Pediatr 92:782

10. Fluharty AL, Meek WE, Kihara H 1983 Pseudo arylsulfatase A deficiency: evidence for a structurally altered enzyme. Biochem Biophys Res Commun 112:191

11. Kihara H, Ho C, Fluharty AL, Tsay KK, Hartlage PL 1980 Prenatal diagnosis of metachromatic leukodystrophy in a family with pseudo arylsulfatase A deficiency by the cerebroside sulfate loading test. Pediatr Res 14:224

12. Langenbeck U, Dunker P, Helpertz R, Pilz H 1977 Inheritance of metachromatic leukodystrophy. Am J Hum Genet 29:639

13. Lott IT, Dulaney JT, Milunsky A, Hoefnagel D, Moser HW 1976 Apparent biochemical homozygosity in two obligatory heterozygotes for metachromatic leukodystrophy. J Pediatr 89:438

14. Lowry OH, Rosebrough NJ, Farr AL, Randall RJ 1951 Protein measurement with the Folin phenol reagent. J Biol Chem 193:265

15. Mehl E, Jatzkewitz H 1965 Evidence for the genetic block in metachromatic leukodystrophy (ML). Biochem Biophys Res Commun 19:407

16. Percy AK, Brady RO 1968 Metachromatic leukodystrophy: diagnosis with samples of venous blood. Science 161:594

17. Porter MT, Fluharty AL, Kihara H 1969 Metachromatic leukodystrophy: arylsulfatase-A deficiency in skin fibroblast cultures. Proc Natl Acad Sci 62:887

18. Reghavan SS, Gajewski A, Kolodny EH 1981 Leukocyte sulfatidase for the reliable diagnosis of metachromatic leukodystrophy. J Neurochem 36:724

19. Rattazzi MC, Marks JS, Davidson RG 1973 Electrophoresis of arylsulfatase from normal individuals and patients with metachromatic leukodystrophy. Am J Hum Genet 25:310

20. Sarafian TA, Fluharty AL, Kihara H, Helfand G, Edmond J 1982 Large scale purification of pyrogen-free human arylsulfatase A. J Appl Biochem 4:126

21. Schaap T, Zlotogora J, Elian E, Barak Y, Bach G 1981 The genetics of the arylsulfatase A locus. Am J Hum Genet 33:531

22. Van der Hagen CB, Borresen A, Molne K, Oftedal G, Bjro K, Berg K 1973 Metachromatic leukodystrophy. 1. Prenatal detection of arylsulfatase A deficiency. Clin Genet 4:256

23. Waheed A, Steckel A, Hasilik K, von Figura K 1983 Two allelic forms of human arylsulfatase $\mathrm{A}$ with different numbers of asparagine-linked oligosaccharides. Am J Hum Genet 35:228

24. Wiesman UN, Meier C, Spycher MA, Schmid W, Bischoff A, Gautier E, Herchkowitz N 1975 Prenatal metachromatic leukodystrophy. Helv Paediat Acta 30:31

25. Zlotogora J, Cohen T, Elian E, Bach G 1980 Letter to the editor: about the inheritance of the arylsulfatase A. Pediatr Res 14:963 